\title{
Salmonella Contamination Risk Points in Broiler Carcasses during Slaughter Line Processing
}

\author{
WALTER RIVERA-PÉREZ, ${ }^{1,2}$ ELÍAS BARQUERO-CALVO, ${ }^{1,3}$ AND REBECA ZAMORA-SANABRIA ${ }^{2,4 *}$ \\ ${ }^{1}$ Veterinary Medicine School, National University, 40206 Heredia, Costa Rica $;{ }^{2}$ Animal Science School, University of Costa Rica, 11501 San José, Costa Rica; \\ ${ }^{3}$ Tropical Diseases Research Program, 40101 Heredia, Costa Rica; and ${ }^{4}$ Animal Nutrition Research Center, 11501 San José, Costa Rica
}

MS 14-052: Received 28 January 2014/Accepted 8 August 2014

\begin{abstract}
Salmonella is one of the foodborne pathogens most commonly associated with poultry products. The aim of this work was to identify and analyze key sampling points creating risk of Salmonella contamination in a chicken processing plant in Costa Rica and perform a salmonellosis risk analysis. Accordingly, the following examinations were performed: (i) qualitative testing (presence or absence of Salmonella), (ii) quantitative testing (Salmonella CFU counts), and (iii) salmonellosis risk analysis, assuming consumption of contaminated meat from the processing plant selected. Salmonella was isolated in $26 \%$ of the carcasses selected, indicating $60 \%$ positive in the flocks sampled. The highest Salmonella counts were observed after bleeding (6.1 log CFU per carcass), followed by a gradual decrease during the subsequent control steps. An increase in the percentage of contamination (10 to 40\%) was observed during evisceration and spray washing (after evisceration), with Salmonella counts increasing from 3.9 to $5.1 \mathrm{log}$ CFU per carcass. According to the prevalence of Salmonella-contaminated carcasses released to trade (20\%), we estimated a risk of 272 cases of salmonellosis per year as a result of the consumption of contaminated chicken. Our study suggests that the processes of evisceration and spray washing represent a risk of Salmonella cross-contamination and/ or recontamination in broilers during slaughter line processing.
\end{abstract}

Salmonella is a zoonotic pathogen distributed worldwide and with significant impacts on the economy and human health; however, few surveillance programs exist due to cost and the current production methods $(4,11,13$, 15). In terms of global productivity, the poultry industry has achieved high standards; however, stronger efforts must be made in order to develop better quality and safety control programs in high-consumption products $(7,13)$. The single evaluation of the final product is becoming insufficient to fulfill the requests of today's buyers, regulators, and customers, who are demanding efficient productive processes and control systems to satisfy modern food standards. The rising technological developments and the increasing global food trade increase the risk of acquiring foodborne diseases, requiring prompt and effective actions to prevent them $(29,13)$. In recent years, governmental and nongovernmental organizations have developed several risk analysis software programs, describing mathematical models to estimate the probability of acquiring an infection after ingesting a given dose of a specific pathogen (12). To create an effective program of prevention and control is difficult because of the complex epidemiology and pathological behavior of this bacterium (7). The aim of the present study was to identify and analyze key sampling points generating a risk of contamination with Salmonella organisms in a

\footnotetext{
* Author for correspondence. Tel: (506) 8863-7547 or (506) 2511-8810; Fax: (506) 2224-5527; E-mail: zamorasr@gmail.com.
}

commercial chicken processing plant and perform a salmonellosis risk analysis. Our data provide reliable information that will help to formulate and implement specific programs to prevent, detect, and control contamination with this pathogen.

\section{MATERIALS AND METHODS}

Processing plant. Sampling for this work was carried out in a commercial processing plant. The processing line speed was 75 birds per min, and each step was performed as follows: bleeding ( $1 \mathrm{~min})$, immersion scalder $\left(53\right.$ to $\left.59^{\circ} \mathrm{C}\right)$, defeathering $(1 \mathrm{~min})$, head removal, internal organ removal (evisceration), spray washing, prechilling, and immersion chilling.

Sampling procedure. Sampling was performed on 10 separate visits over a 5-month period in 2012 (January to May). On each visit, one carcass was taken from each of nine different sampling points of the processing line, making nine carcasses from each trip for a total of 90 birds. Samples were taken after the following procedures: (1) bleeding (with feathers still attached), (2) scalding, (3) defeathering, (4) cutting the cloacae and abdominal opening, (5) evisceration, (6) spray washing, (7) prechilling, (8) chilling, and (9) packaging and shipping. All the birds sampled came from the same flock.

Whole carcasses were randomly selected at each sampling point, using the methodology suggested by the U.S. Department of Agriculture Food Safety and Inspection Service for collecting raw meat and poultry product samples (27). Briefly, carcasses were placed in sterile bags and rinsed with $400 \mathrm{ml}$ of buffered peptone water (Oxoid, Cambridge, England) for $1 \mathrm{~min}$. Samples were 
TABLE 1. Percentage of carcasses contaminated with Salmonella and total Salmonella counts per sampling point

\begin{tabular}{lcc}
\hline $\begin{array}{c}\text { Sampling point and } \\
\text { processing stage }\end{array}$ & $\begin{array}{c}\text { \% of carcasses } \\
\text { contaminated }\end{array}$ & $\begin{array}{c}\text { Salmonella count } \\
(\log \text { CFU/carcass) }\end{array}$ \\
\hline 1. Bleeding & 60 & 6.1 \\
2. Scalding & 30 & 3.6 \\
3. Defeathering & 30 & 3.9 \\
4. Cut cloacae & 10 & $\mathrm{NR}$ \\
5. Evisceration & 40 & 3.9 \\
6. Spray washing & 10 & 5.1 \\
7. Prechilling & 20 & $\mathrm{NR}$ \\
8. Chilling & 10 & $\mathrm{NR}$ \\
9. Shipping & 20 & $\mathrm{NR}$ \\
\hline
\end{tabular}

${ }^{a}$ Nine birds were analyzed per sampling point. NR, no Salmonella colonies recovered. Detection limit for Salmonella counts (quantitative test) was 4,000 CFU per carcass.

placed in coolers $\left(0\right.$ to $\left.4^{\circ} \mathrm{C}\right)$ and transported to the laboratory for analysis.

Microbiological examinations (qualitative analysis). The percentage of Salmonella contamination (incidence) was determined using the methodology recommended by the U.S. Department of Agriculture Food Safety and Inspection Service for the isolation and identification of Salmonella (28). Primary culture was performed by first adding $30 \mathrm{ml}$ of sample rinse fluid to $30 \mathrm{ml}$ of sterile buffered peptone water (Oxoid) and homogenizing the mixture; then, samples were incubated at 36 $\pm 1^{\circ} \mathrm{C}$ for $24 \mathrm{~h}$ and $0.5-\mathrm{ml}$ and $0.1-\mathrm{ml}$ amounts transferred to $10 \mathrm{ml}$ of tetrathionate broth (Acumedia, Lansing, MI) and $10 \mathrm{ml}$ of Rappaport-Vassiliadis broth (Acumedia), respectively. Tubes were incubated in a water bath at $42 \pm 0.5^{\circ} \mathrm{C}$ for $24 \mathrm{~h}$. Next, a loopful from each enrichment broth was streaked onto a xylose lysine Tergitol 4 agar (XLT4) (Acumedia) and a brilliant green sulfa agar (Acumedia) plate and incubated for $24 \mathrm{~h}$ at $35 \pm 2^{\circ} \mathrm{C}$. Following this, typical Salmonella colonies were inoculated onto triple sugar iron agar (Merck, Darmstadt, Germany), lysine iron agar (Oxoid), and urea Christensen agar (Oxoid) and incubated at $37^{\circ} \mathrm{C}$ for $24 \mathrm{~h}$. Reactions compatible with Salmonella were confirmed biochemically with API 20E (BioMériux, Marcy l'Etoile, France) and with specific Salmonella omnivalent O agglutinating antisera (Seiken, Tokyo, Japan).

Microbiological examinations (quantitative analysis). Salmonella quantification analysis (CFU per carcass) was conducted by performing a dilution counting protocol, using XLT4 as the selective agar (experimental protocol tested in the present study). Sample rinse fluid was serially diluted $\left(10^{-1}, 10^{-2}\right.$, and $\left.10^{-3}\right)$ in buffered peptone water, and 100- $\mu \mathrm{l}$ amounts plated as duplicates on XLT4 agar plates using a Drigalski spatula. The plates were incubated at $35 \pm 1{ }^{\circ} \mathrm{C}$ for $24 \mathrm{~h}$, and typical Salmonella colonies were assessed as previously described. Counts were performed in CFU per milliliter. Carcasses were rinsed with $400 \mathrm{ml}$ of sterile peptone water, and the count of CFU per carcass was obtained by multiplying the CFU per milliliter value by 400 . The detection limit for Salmonella counts (quantitative test) was 4,000 CFU per carcass.

Estimation of disease risk. To estimate the risk of human disease caused by eating Salmonella-contaminated chicken meat from the processing plant evaluated, a risk assessment model proposed by the World Health Organization for eggs and broiler chickens was applied (12). The risk assessment model estimates the probability of human disease caused by the ingestion of Salmonella for the entire chicken meat production chain. The risk is calculated based on the prevalence of contaminated chicken carcasses at the end of processing in the plant. The model includes handling and cooking practices at home, establishing a mathematical dose-response relationship between the ingested dose of Salmonella and the chance of human disease. The probability of disease was calculated from the number of organisms ingested, information on the dose-response relationship, and adjusted data from outbreaks. The number of bacteria consumed was obtained using the weight of chicken meat consumed per serving and the number of Salmonella organisms in the meat.

Statistical analysis. Data collected from all samples were analyzed descriptively and tabulated using Excel 2007 software (Microsoft, Redmond, WA). Analysis of variance and multiple range test (Duncan's test) were applied using the general linear model Infostat 2012 software and a probability of $\alpha<0.05$.

\section{RESULTS AND DISCUSSION}

Salmonella was detected at every sampling point of the processing line. The contamination detected at every sampling point is shown in Table 1. Of all the steps of the processing line, sampling point 1 had the highest percentage of contamination $(60 \%)$. Although a high percentage, this contamination rate was still lower than others reported by other authors (as high as 98.9\%) (18). Since the first sampling was performed soon after the birds arrive at the plant, the risk of cross contamination was very low. The main risk at this point is the potential contamination introduced by the staff hanging birds at the entrance of the processing line, which is considered a step with minor microbiological implications. Salmonella isolated at this point are usually acquired on the farm and/or during transportation to the processing plant. Several studies show that the sacrifice of Salmonella-positive flocks augments the risk of contaminating subsequent flocks in the processing line, increasing from 30 to $70 \%$ the incidence of Salmonella $(10,23)$.

In following the processing flow (points 2, 3, and 4), a gradual decrease in contamination was observed, reaching one of the lowest percentages of contamination of the study. This dynamic indicates that the procedures of scalding, defeathering, and cutting of the cloacae and abdominal opening reduced the Salmonella present on the carcasses sampled. Other studies indicate that procedures such as scalding and defeathering may produce a significant increase in the risk of cross contamination $(5,13,20)$.

As observed from the data in Table 1, an increase in the percentage of contamination (40\%) was detected at sampling point 5 (evisceration), suggesting that the evisceration process increased the risk of contamination with Salmonella. Our results agree with those obtained in a previous study conducted in Costa Rica (3), showing a significant increase in the percentage of positive samples during the evisceration process. This augmentation may be due to cross contamination, either by the operators and/or the equipment. This result suggests that the evisceration process was performed incorrectly, allowing dispersal of the gastrointestinal-colonizing bacteria. During this process, 
viscera are normally removed violently; the incisions in the intestinal package may spread the bacteria throughout the carcass. Operators can also transfer bacteria to noncontaminated carcasses by manipulation. Carcass contamination by intestinal bacterial during inappropriate evisceration has been previously reported (25).

After the following processing steps (points 6, 7, and 8), contamination decreased again due to carcass wash and treatment in the prechiller and chiller. Previous works have shown that prechiller and chiller treatments can be quite efficient in eliminating bacteria and preventing bacterial multiplication if the water flow and chlorine levels are strictly controlled $(3,21)$. At the last sampling point (shipping), when the broiler carcasses were ready for shipping and trade, we found a Salmonella contamination rate of $20 \%$.

The increased contamination observed between points 8 and 9 probably occurs during the waiting time (60 minutes maximum) or during handling of carcasses from the chiller to the packaging and storage area in the cold room. Other authors agree and indicate that, during this stage, the carcasses may have a higher incidence of Salmonella because bacteria from contaminated carcasses can adhere to wet surfaces and form biofilms, providing a source of crosscontamination to carcasses processed subsequently $(9,30)$.

Salmonella counts in XLT4 agar. As shown by the data in Table 1, there was a high rate of Salmonella contamination at the beginning of the process, reaching a total of $6.1 \mathrm{log}$ CFU per carcass. After scalding, the quantities of Salmonella decreased to $3.6 \log$ CFU per carcass and remained relatively constant at the following sampling point; however, an increase in the counts of Salmonella was detected at sampling point 6 (spray washing), reaching 5.1 log CFU per carcass.

Higher Salmonella counts after spray washing can be explained by the concept of weak bacterial attachment that was previously reported $(14,17,26)$. According to this notion, bacteria exposed after an inadequate evisceration are weakly attached to the carcass. This bacterial attachment is time dependent, and the process is relatively fast $(2,14,26)$. Consequently, bacteria could be easily spread to other parts of the carcass or contaminate adjacent carcasses during water spraying. Sprayed bacteria are most likely dispersed to the folds and cracks of the skin, where they remain trapped. At sampling points 7,8, and 9, no Salmonella colonies were recovered, indicating that the following disinfection treatments (prechiller and chiller) effectively reduced the viable bacterial loads below 4,000 CFU per carcass.

An increase of Salmonella counts after sampling point 6 (spray washing) shows that the washing process was ineffective to control Salmonella and introduced a high risk of contamination.

The experimental quantitative protocol (direct XLT4 plating) applied in this study proved to have a low sensitivity, since only $21.7 \%$ of all samples that were positive by the standard Salmonella qualitative protocol (presence/absence) were detected with the quantitative method. Other authors have developed and evaluated other methodologies to quantify Salmonella in samples, such as spiral plate count, hydrophobic membrane filtration, most probable number, and real-time-PCR, reporting sensitivities ranging from 38.8 to $100 \%(1,6,8,15,24)$.

Estimation of annual salmonellosis. Applying all assumptions proposed in the World Health Organization prediction model (12), in concert with specific data from the country (population of 4,301,712, 71.8\% of whom regularly consume chicken) (16, 19), chicken meat consumption habits (22.4 kg per capita, with a weekly consumption frequency) (22), and assuming that the process plant evaluated represents $15 \%$ of the national production of chicken meat, it was estimated that a total of 272 cases of salmonellosis could occur in 1 year as a result of consuming Salmonella-contaminated chicken from the processing plant evaluated.

Disease risk analysis can be used to evaluate the efficacy of a safety intervention strategy in the production process of a processing plant. Any intervention resulting in a reduction of Salmonella-contaminated carcasses (final stage of process) would directly reduce the risk of acquiring the disease. In the same manner, if other safety strategies are applied (e.g., reduction of Salmonella CFU counts), the number of Salmonella cases would also be reduced.

Comparing the results of this risk analysis to the actual data reported by the World Health Organization (31) in 2010 (186 Salmonella cases), there was no correlation between the historical and the model-projected data. Although Costa Rica salmonellosis may be underreported, this might also suggest that the model established by the Food and Agriculture Organization of the United Nations and the World Health Organization (12) may not represent the reality for this country.

These data provide reliable information that will help to formulate and implement specific programs to prevent, detect, and control Salmonella. Moreover, this study provides scientific evidence supporting the knowledge that the prevalence of Salmonella in a processing plant is the result of several individual practices along the processing line. The prevention of Salmonella contamination requires a detailed knowledge of the main risk factors associated with their occurrence in the production system.

\section{ACKNOWLEDGMENTS}

We are grateful for the technical support of the Laboratory of Bacteriology, Veterinary Medicine School, National University (UNA), and Mr. Hugo Sánchez-Zumbado. We declare that no competing interests exist.

\section{REFERENCES}

1. Abdunaser, D., F. Almabrouk, W. Ashraf, M. Yves, C. Olivier, and S. Moez. 2009. Combination of most-probable-number method with light cycler real-time PCR assay (MPN-real-time PCR) for rapid quantification of Salmonella in artificially and naturally contaminated bovine fecal samples at slaughter house. Iraqi J. Vet. Sci. 23(Suppl. II):231-243.

2. Allen, V., D. Tinker, M. Hinton, and C. Wathes. 2003. Dispersal of micro-organisms in commercial defeathering systems. Br. Poult. Sci. 44:53-59.

3. Arosemena, A. 2000. Determinación de la contaminación de Salmonella sp. en carne de pollo parrillero en Costa Rica utilizando el sistema de análisis de peligros y puntos críticos de control 
(HACCP). Master's thesis. Universidad Nacional, Heredia, Costa Rica.

4. Bailey, J., N. Stern, P. Fedorka, S. Craven, N. Cox, D. Cosby, S. Ladely, and M. Musgrove. 2001. Sources and movement of Salmonella through integrated poultry operations: a multistate epidemiological investigation. J. Food Prot. 64:1690-1697.

5. Berrang, M., R. Buhr, J. Cason, and A. Dickens. 2001. Broiler carcass contamination with Campylobacter from feces during defeathering. J. Food Prot. 64:2063-2066.

6. Borowsky, I., V. Schmidt, and M. Cardoso. 2007. Estimation of most probable number of Salmonella in minced pork samples. Braz. J. Microbiol. 38:544-546.

7. Bravo, E. 2011. Programas de prevención y control de especies de Salmonella de interés para la salud humana ( $S$. Enteritidis y $S$. Typhimurium). In Memoria I Seminario Internacional sobre Salmonelosis Aviar, Asociación Latinoamericana de Avicultura (ALA) y la Asociación Brasileña de Avicultura (UBABEF), Río de Janeiro, 28 a 30 de Junio de 2011.

8. Brichta-Harhay, D., T. Arthur, and M. Koohmaraie. 2008. Enumeration of Salmonella from poultry carcass rinses via direct plating methods. J. Appl. Microbiol. 46:186-191.

9. Chaves, B., I. Han, P. Dawson, and J. Northcutt. 2011. Survival of artificially inoculated Escherichia coli and Salmonella Typhimurium on the surface of raw poultry products subjected to crust freezing. Poult. Sci. 90:2874-2878.

10. Conner, D., and C. Wakefield. 2006. Incidence of Salmonella in processed broilers following transportation in contaminated coops, paper 127. In Memorias del XII European Poultry Conference, Verona, Italy, 10 to 14 September 2006.

11. Donado, P., V. Clavijo, M. Leon, M. Tafur, S. Gonzales, M. Hume, W. Alali, I. Walls, D. Wong, and M. Doyle. 2012. Prevalence of Salmonella on retail broiler chicken meat carcasses in Colombia. $J$. Food Prot. 75:1134-1138.

12. Food and Agriculture Organization of the United Nations and World Health Organization. 2002. Risk assessments of Salmonella in eggs and broiler chickens. Microbiological Risk Assessments Series 2. Food and Agriculture Organization of the United Nations and World Health Organization.

13. Goksoy, E., S. Kirkan, and F. Kok. 2004. Microbiological quality of broiler carcasses during processing in two slaughterhouses in Turkey. Poult. Sci. 83:1427-1432.

14. Guerin, M., C. Sir, J. Sargeant, I. Waddell, A. O'connor, R. Wills, R. Bailey, and J. Byrd. 2010. The change in prevalence of Campylobacter on chicken carcasses during processing: a systematic review. Poult. Sci. 89:1070-1084.

15. Hue, O., S. Le Bouquin, F. Lalande, V. Allain, S. Rouxel, I. Petetin, S. Quesne, M. Laisney, P. Gloaguen, M. Picherot, G. Salvat, S. Bougeard, and M. Chemaly. 2011. Prevalence of Salmonella spp. on broiler chicken carcasses and risk factors at the slaughterhouse in France in 2008. Food Control 22:1158-1164.

16. Instituto Nacional de Estadística y Censos. 2011. X Censo nacional de población y VI de vivienda 2011: resultados generales. Instituto Nacional de Estadística y Censos, San José, Costa Rica.

17. Jiménez, S., M. Salsi, M. Tiburzi, and M. Pirovani. 2002. A comparison between broiler chicken carcasses with and without visible faecal contamination during the slaughtering process on hazard identification of Salmonella spp. J. Appl. Microbiol. 93:593598.

18. Mellor, G., I. Duffy, G. Dykes, and N. Fegan. 2010. Relative prevalence of Salmonella Sofia on broiler chickens pre and post processing in Australia. Poult. Sci. 89:1544-1548.

19. Ministerio de Salud de Costa Rica. 2001. Encuesta Nacional de consumo de alimentos. Ministerio de Salud de Costa Rica, San José, Costa Rica.

20. Nde, C., J. McEvoy, J. Sherwood, and C. Logue. 2007. Cross contamination of turkey carcasses by Salmonella species during defeathering. Poult. Sci. 86:162-167.

21. Northcutt, J., J. Cason, D. Smith, R. Buhr, and D. Fletchert. 2006. Broiler carcass bacterial counts after immersion chilling using either low or high volume of water. Poult. Sci. 85:1802-1806.

22. Pérez, E. 2011. La evolución reciente de la producción de carnes en Costa Rica. Rev. ECAG Informa 55:64-66.

23. Rasschaert, G., K. Houf, and I. De Zutter. 2007. Impact of the slaughter line contamination on the presence of Salmonella on broiler carcasses. J. Appl. Microbiol. 103:333-341.

24. Ristori, C., A. Morato, R. Gravato, G. Lopes, A. De Paula, M. De Oliveira, E. Abeid, J. De la Torre, S. Prado, J. Yoshida, R. Rodrigues, O. Taha, D. Marsiglia, and M. Jakabi. 2008. Quantificação de Salmonella spp. e avaliação dos dizeres de rotulagem de carcaças de frango congeladas comercializadas no Estado de São Paulo. Bol. Epidemiol. Paul. 5:16-19.

25. Russell, S., and J. Walker. 1997. The effect of evisceration on visible contamination and the microbiological profile of fresh broiler chicken carcasses using the $\mathrm{Nu}$-Tech evisceration system or the conventional streamlined inspection system. Poult. Sci. 76:780-784.

26. Smith, D., J. Northcutt, J. Cason, A. Hinton, R. Buhr, and K. Ingram. 2007. Effect of external or internal fecal contamination on numbers of bacteria on prechilled broiler carcasses. Poult. Sci. 86:1241-1244.

27. U.S. Department of Agriculture, Food Safety and Inspection Service. 1998. Salmonella analysis: collecting raw meat and poultry product samples. U.S. Department of Agriculture, Food Safety and Inspection Service, Washington, DC.

28. U.S. Department of Agriculture, Food Safety and Inspection Service. 2011. Isolation and identification of Salmonella from meat, poultry, pasteurized egg and catfish products, chap. MLG 4.05. In Microbiology laboratory guidebook. U.S. Department of Agriculture, Food Safety and Inspection Service, Washington, DC.

29. Villoch, A. 2012. La calidad en la producción de alimentos en las cadenas agroalimentarias, p. 1-16. In L. Vazquez, A. Villoch, and G. Ramos (ed.), La inocuidad como estrategia de competitividad para la producción de carne de cerdo. Red Porcina Iberoamericana, México, D.F., México.

30. Voidarou, C., D. Vassos, T. Kegos, A. Koutsotoli, A. Tsiotsias, J. Skoufos, A. Tzora, V. Maipa, A. Alexopoulos, and E. Bezirtzoglou. 2007. Aerobic and anaerobic microbiology of the immersion chilling procedure during poultry processing. Poult. Sci. 86:1218-1222.

31. World Health Organization. 2010. Global foodborne infections network: top 15 lists from a country, parameters. Available at: http://thor.dfvf.dk/pls/portal/gss.country_data_set_rep.show_parms. Accessed 15 July 2013. 